\title{
Women's Sexuality through Ratauli Songs in Hindu Society
}

\author{
Bishnu Prasad Dahal, Ph. D. (Corresponding author) \\ Asst. Professor \\ Patan Multiple Campus, Patan Dhoka \\ Tribhuvan University, Kathmandu, Nepal
}

\begin{abstract}
Received: November 9, 2020 Accepted: November 30, 2020 Published: December 15, 2020
doi:10.5296/jad.v7i1.18071 URL: https://doi.org/10.5296/jad.v7i1.18071
\end{abstract}

\begin{abstract}
The aim of this research is to identify the voices of women, about their sub- ordination, oppression that has been practiced in Nepalese society and culture through the analysis of lyrics of Ratauli songs. The contradictions between the myths about gender and real experienced (by suffered in realist manner) is also over looked and tried to analyze the situation experience by Women and non-women in Nepali society. To understand the socio-cultural feeling, emotion, aspiration, lyrics of music may be the probable means to analyze what message is provided, what is understood by the people. How message can help to unite the people and what is the role performed by these lyrics of music in society and culture in physical as well as socio-cultural sphere in society and culture.

General objectives of this research are to identify the nature, types and dimension of Ratauli songs. Specifically, the formation of Ratauli songs, their contents with various dimensions, culture, social context and time relative are also researched here. The conducted research explored more about different aspects of Ratauli songs their contexts and its formation in different time periods as well as carried contents and their messages. This research found comparisons between the context and content of Ratauli songs in different time.
\end{abstract}

Keywords: Ratauli, Ratauli songs, marriage, wedding ritual, events, sexuality, patriarchy etc

\section{Introduction}

Lyrics of music as an art is part of human beings, magnificently interpret the total socio-cultural world. Lyrics can embody and transcend both its creators and its times to reveal enduring truths about the human condition, the more we understand the meaning and messages of lyrics, the more we understand ourselves, our society, our culture (both material 
and non material) including our behavior and relationship too and even the complexities of our world.

Lyricist can visualize the socio-cultural circumstances in his/her wording, while musician can compose that song in composite pattern with his way of interpretation. Likewise, singer sings the song, and listener understands the message that is passed by lyricists, that was happened or is being happened in the particular circumstances. All these artists sought to make visible the ground reality of the culture and emotions, aspirations, feelings and experiences of the people that was fabricated in terms of his/her behavior in music/lyrics and others. Each lyric acquired diverse techniques of expression with which could faith fully replicates or manipulates reality.

Feminist theory is dialogically constituted the debate on the pluralism that characterizes both anthropology and feminist discipline while dealing about women's world seem to have them touch them mutual ground at several points, and these fields of studies are found more or less the contrast with natural science; one finds diverse 'schools' (also true in science) but also that their premises are by their nature constructed competitively in relation to one another. The study of women's world in social anthropology can persistently divided into two camps over whether or not sexual asymmetry is universal. One side argued that Western constructs blind us from seeing egalitarianism in unfamiliar contexts and that we encountered hierarchical relations only in the historical context of privatized ownership. The other side argues that we should look for sexual inequality in all its forms, for sexual difference everywhere contributes to socially constituted differences.

Ratuali as a part of wedding ceremony is an event of the Hindu weeding rituals that takes place in the groom's house after the male participants of the men's wedding party have departure to the bride's house, leaving behind all women allegedly 'safe' in the home. It is also important to know that the Ratauli events take place on the occasion of the wedding of so-called high caste people of Nepal particularly in Brahmins and Chhetris. Ratuali ceremony is an exclusively female events or processes without male participation. Males of all ages are prohibited to participate; they might face insults, teases or even beating should they only try to approach. Mainly Ratauli is primarily associated with the groom's mother, sisters, and his other female relatives who may participate in the Ratauli until the wedding party of the groom returns with the bride next morning, but now a day the wedding ceremony held during day time. This is a closed ceremony where the women of the groom's household must stay up night, keeping the light burning while the groom and the bride are performing actual marriage ritual scheduled at the bride's house. The important components or the focus of the Ratauli are to make fun of heterosexuality, to make jocks about the sexual interaction through women dancing impersonating the male part as well (Kondos, 2004).

That's why the aim of this research is to identify the voices of women, about their subordination, oppression that has been practiced in Nepalese society and culture through the analysis of Ratauli songs. The contradictions between the myths about gender and real experienced (by suffered in realist manner) is also over looked and tried to analyze the situation experience by Women and non-women in Nepali society. 


\section{$\Lambda$ Macrothink}

Society, culture cannot be understood only by using participant and observation methods. The realistic and valid information are gathered by using primary methods cannot be generalized everywhere. Some researchers can be done without using these methods of information collections according to its nature. The nature of study determines the methods of information gathering. Society can be understood through the analysis of message that is given by social actors in terms of lyrics of music as well as other artistic expression. This type of expression deals with the feeling, aspiration and emotion of individual, community and society as well.

But, it may not necessarily to fabricate uniformly. It varies according to time and society/culture. To understand the socio-cultural feeling, emotion, aspiration, lyrics of music may be the probable means to analyze what message is provided, what is understood by the people. How message can help to unite the people and what is the role performed by these lyrics of music in society/culture in physical as well as socio-cultural sphere in society/culture.

Concerning gender setting, the most important point made is that gender construction is through the socio-cultural construction and it is dynamic too. The change in context of society and culture ultimately changes in the content of music particularly the songs. An introduction to the anthropological view points of 'music as culture' was also introduced here. Some facts about 'ritual as culture' especially Ratauli as a ritual was introduced more from anthropological point of view. Furthermore, I have outlined the focus of my research, introducing the Geertzian model of symbolism, where society and cultural context were visualized through a particular ritual. That's why my research was heavily influenced from his model and can be expressed as "Women through Ratauli". Similarly, Bakhtian (1986) concept is also juxtaposed here wherever it was fitted. Defining Ratauli songs was quite problematic here, because situation, context, etc. along with material and non-material components of Nepali culture and society were changing according to time and space. Moreover, the emotional aspect- or the 'ethos' in the terms of Gregory Bateson (1979), was singled out as a most important constituent of the experience of music performance.

Ratauli as an event described as a means of expressing women's feeling, emotions, sentiments, religions, rituals, politics, and culture or complex whole of society. In this religious ritual, women expressed their problems, experiences and many more and those problems were more common to all who live in society. Gender relations, dominations harmony were common social dimensions related in society. Language as the structure of society, and if structure was clear then society would be clearly understood. The research problem set up here was: society is made of different elements and it can be understood by knowing its elements through particular events. Ratauli as a religious ritual event function in Nepali society and culture as means or source of knowledge for analyzing gender relation, differences, inequality and so on. Through Geertzian model (1973) events provided complex and multiplex information about society and culture. So, it was rational to study society and culture through events because studies of them take more time and resources. The simple and valid way of generating knowledge on socio-cultural matter was to study through events. Symbolic theory in anthropology was the best way to study events by using qualitative methods of analysis. Ratauli songs were by product of Nepalese society and culture and study 
about it represents the study of culture and society. Ratauli as events help to identify socio-cultural problem that existed in the society and dynamism of society and culture ultimately changed the contents and contexts of Ratauli songs. Women through Ratauli songs were the main topic of research through which we could find out socio-cultural problems, existing situations, and so on.

This research aims to present and examine the lyrics of Ratauli songs as vehicles of women's social commentary on women's lives and male privilege in Hindu society. The creation and performance of recent Ratauli songs as observed in Nepal are investigated to reveal the dynamics and cultural production of meanings that occur in Ratauli and to place these productions in their wider socio - cultural context.

\section{Theoretical Review}

The culture is public, because meaning is public. It is expressed in symbolic actions and meanings are contextual. So, culture contexts of a particular cultural settings in which they are operated; meanings may change in another context. The Geertzian model (1973) of symbolic anthropology focuses on the meaning of the cultural activities not to the functions per se. Such activities are analyzed to open up meanings of other aspects of the culture. For Geertz, the idea about a culture is like a literary text that can be analyzed for meaning, as the ethnographer interprets. Like ethnographers, cultural interpretations try to convey the symbols of culture and their meanings to those people who are really interested about their own culture or those who are interplaying within these cultural contexts. Therefore, according to Geertz, the ethnographer is a kind of selective inter- cultural translator. In the case of research paper I have tried to explain, to interpret, to describe the Ratauli and women's sexuality in Hindu society as ethnographer, to elaborate the cultural artifacts in that particular cultural context.

Geertz in thick description argues the aim of anthropology is to interpret the "meaning of behavior" to explain actions and attitudes that appear puzzling. According to him, culture consists of "structure of significance", "frame of interpretation" or socially established structures of meaning. For him, culture is context and it is the object to the ethnography to describe it. "The interpretive study of culture represents an attempt to come terms with the diversity of the ways human beings construct their lives in the acts of leading them"(Geertz, 1973).

The French anthropologist Claude Lévi-Strauss argued that the method of thinking as systems of differences could be applied generally to social phenomena. He applied it particularly to the study of myths, arguing that stories which appeared quite unintelligible to us could be shown to make sense and to have a rigorous order. Levi -Strauss claimed that if we think of the characters and events in terms of contrasts, of opposites, and then there appears much greater order, one which is almost mathematical (Cuff et.al, 1990).

Levi -Strauss says that the difference between us and primitive is entirely superficial. The human mind is everywhere the same because the human brain (like a computer) operates through binary oppositions, that is contrasts. Primitive though like myth is every bit as 
sophisticated, complex and intellectual as our own, though it expresses itself in different ways. Two big possibilities arise. Firstly, social phenomena in general can be regarded as phenomena of communication, involving the organization of systems of signs, that is the structure of language and meanings that, as we shall see, shape up the actions of individualshence the label structuralism. He argues that primitive kinship systems, perennial puzzles for anthropologists, could be better understood if they were taken as ways of sending messages between social groups (Levi-Strauss, 1969).

In Seeger's view(1987), the way in which music performance is a part of the construction of social process and experience is often not fully realized, neither in the anthropology of music.

Symbolically, Ratauli represents socio-cultural and sexual life of women, but plane of angle to visualize Ratauli festival and understanding message of Ratauli songs may be different. Socialization, enculturation, assimilation, cultural contacts, etc. make people different both in presentation and understanding content of messages that were delivered by Ratauli songs. Ratuali associated with complex socio-cultural whole and it provides message that is multivocal in nature. Psychic unity and psychology, attitudes, norms, values etc. make different way of understanding cultural events and message and meaning delivered by that message in that particular context. Audiences are varied according to the nature of their psychic unity, so though delivered message provides same meaning but it is understood differently because of multi-vocabulary. It is cleared from the audiences that understood message and meaning are completely different according to persons, culture and society.

The most central aspect of the Ratauli performances (Songs) was how their life pattern seemed to influence and enhance the emotional experiences of other women or her. In this sense, Ratauli performances became a significant factor in daily life of women. The emotional, recreational, sentimental and others expressions in Ratauli songs proved that all these human expressions were during the human interactions and were natural. All society and culture possessed these things and one contradicts others, as they were known to strike their listeners, by rendering into Ratauli songs, the stories of household, gender relations, patriarchy, mobility, beauty and cosmetics of our society and culture and importantly, the construction of sexuality of women in Hindu orthodox society. At the end, I like to know, how useful is my application of Greetzian and Bakhtinian concepts of 'symbolism through event' and 'chronotopoe' in describing construction of sexuality of women and their voices through Ratauli songs according to time and space. It seemed likely that my theoretical orientation have drawn the focus of my research in a specific direction. How significant was my orientation in this context?

I have also pointed out that the Ratauli songs represent the voices of all women all over the country, society, and culture, though it is highly practiced in high caste Hindu. Not only the case of women, other cases like, caste, class, gender, ethnicity, religion, region, ecology, etc. are also in same position as we are analyzing the situation, and position of women. Thus, it represents all of them because all these are the product of society and culture. They are dynamic too. Because of dynamism, the changes have taken place. That's why; any songs may be the probable means to express the human sentiments, emotions, feelings and even 
other socio-psychological, behavioral activities and performance of particular context of the society. So, the study of songs efficiently provide the clear cut understanding about society, culture and even behaviors of human in this world.

\section{Methodology}

Here, about research methods, tools and techniques it was dealt. Defined universe, selecting samples, and its procedure were clearly mentioned. Content analysis of Ratauli songs and lyrist survey were the newly introduced as methods of data collection and information gathering tools and techniques. Variables were defined clearly and their relations with other variables were presented so as to conduct and precede research scientifically and concept of detailed research was conceptualized and it made research in pattern and helped more to make it empirical. So importantly, I selected appropriate methods of data collection tools and techniques, appropriate research design and so on. About time and area of research were also described properly.

Purposively, eight (8) events of Ratauli of wedding ceremony were selected where Ratauli were conducted so as to identify the Ratauli songs in which sexual contents were selected, presented and critically analyzed the content and the context of the Ratauli songs particularly sexual contents through which we can understand the context of contemporary construction of sexuality among women in Hindu orthodox society through symbolic interpretation. Content analysis in lyricist survey is the methodology to generate the information about the Ratauli songs, their content and context. The singers itself act as lyricist and composer, as key informants were interviewed or discussed so as to generate information primarily. The focus group discussions (FGD) were carried out in Kathmandu valley.

This study was carried out in Kageshwori- Manahara Municipality and Shankarapur Municipality, typically they are well known by the name of 'Katha"-peri-urban area of Kathmandu Valley, on the day of marriage ritual of groom from- 2018-2019, when women were celebrating the marriage ritual of groom after the male departure to the bride's house in the village. So my keen interest was to explore the construction of sexuality of women in Hindu society through the Ratauli songs.

\section{Presentation and Discussion}

It is found that the from the ethnographic fieldwork on Ratauli songs, major finds are as follows;

\subsection{Culture and Society: Contexts and Contents}

Everyday life in Nepal is to a great extent fixed or regulated by ritual activities. A vast number of festivals and rituals are celebrated according to the yearly cycle of the Nepalese calendar. But occasionally, there are extra festivals, ceremonies and events which are also pay significant role in the socio-cultural and psychological life of people. Ratauli is such a ritual or event functions as the one of the important role in the sharing, expressing, interacting women's voices especially sexuality in Hindu society. Nepal is also known as the 'land of festival'. The Nepalese Hindu calendar, being divided into a series of auspicious and 
inauspicious events, will be the regarding force of a vast number of social activities, however, the celebration of festivals and seasonal rites are locally organized in different ways as they may vary from neighborhood to neighborhood even inside each 'ethnic group', 'caste', or 'jat' (Weisethaunet, 1998),

The more I came to know about Nepalese ritual life, and in particular that of women celebratation, the more I have also known the impact of diversity regarding the ritual activities. The particular religious festival do have their own rules and meaning, however, their contents, symbols, and local meanings, seem to vary a great deal in detail not only from ethnic group to ethnic group but also from place to place and neighborhood to neighborhood and from gender to gender.

In Nepal, music performance is very central to the ritualizing of time through religious, social, and ritual activities. A central question to be raised thus is, how is the relation between music (especially message) and society to be conceived? My reflections around the topic of lyrics of songs as a ritualized activity may be seen as very much influenced by the work of Field (1984) and Seeger (1987). According to Seeger, music is not just something which happens 'in' society. A society, Seeger (1987) argues, might also be usefully conceived of as something which happens 'in music'. As argued by Seeger, it is through music and dance performance that fundamental aspect of Suya, social organization is recognized: social time is ritually articulated. Such is also the role of music and ritual among the women and a vast number of other Nepalese peoples. In Nepal, music performance and the celebration of auspicious and inauspicious events and festivals are ritualizing time, inhabiting time, giving time its collective and individual meaning (Seeger, 1987).

In principle, the musical experience cannot be thought of as substitution with other areas or kind of experience. Musical engagement represents, an aesthetic experience conceived of fully of its own value. This does not indicate that the musical experience is valued without a base in other areas of experience. Its meaning is realized through its relation to real life, as a part of that life, and not as separated from the general field of cultural experience. However, in certain cases, it may challenge the common; the well known; the acceptable; the dominant view of a culture and discourse. In the Western art discourse (from Burke and Kant to Lyotard), the aesthetic is thought to have its counterpart in the concept of the sublime. From an anthropological point of view, I have found it problematic to take such exalt categories as the basic starting point of description. This is because processes of cultural experience, along with the discursive representations of emotional categories, seem not universal but, rather, inherently cultural and heterogeneous. As such, there is obviously an intrinsic relation between the aesthetic experience and the cultural content from which it emanates. Anthony Seegers's monograph, Martin Stokes argues, is a powerful argument which, amongst other things, "overcomes the theoretical divide between the study of music and the study of society" (Stokes, 1994).

According to Feld, "it is one of a small number of recent ethno-musicological monographs of remote 'tribal' peoples, in which our own distinctions between the ritual and the technical, the cultural and the natural, music, dance, speech and other forms of communication have to be 
rethought from scratch" (Feld, 1982). Ritual is a process where the stories of the past are re-created, or may be more preciously created, and a kind of performance (processes) which enhances what $I$ in this chapter will term 'occasional or ceremonial ritual or event'. Concerning the relation between myth and ritual as an essential point is that because the past can only be seized hold of as memory (as expressed by Benjamin), myth and predecessorial beliefs are not memory created and maintained once and for all. In fact, myth and ancestral stories have to be repeated over and over again to exist. This is the purpose of ritual or events.

\subsection{The Ratauli Songs and the Sexuality of Women}

The study of relations, which encompasses the interactions between the two sexes, is a prerequisite to understanding the situation of any gender. Gender relations include the relative social position of women and men and how this social status changes in different contexts. Gender relations are constructed and maintained through a complex array of factors that are formed, according to social, cultural and historical circumstances (Dahal, 2008). The aim of this study about Ratauli songs is the study of power relation between patriarchy and women and women and women in Nepalese society and culture. How this power relation is institutionalized and practiced in everyday life from family to the state and inter and intra gender relationships to reproduce, to maintain and to change to hierarchical and unequal gender relationships?

There is universal biological difference between male and female, but their role and status varies, according to cultural conditioning and social structure. So, anthropologists have turned to all the theoretical perspectives to understand the social relationships based on gender, i.e. how and why social distinctions between females and females of different status are established? Each approach focuses on culture rather than biology, as the primary determinant of social viz. gender relationships. In feminist writing 'sexuality' refers to an aspect of personal and social life that has erotic significance: not only erotic desires, practices and identities but also the discourses and social patterns which construct erotic possibilities. Essentialists and biological determinists argue that women's sexual (i.e. biological) difference from men is the main cause of women's oppression. But feminist constructivists' counterargues that it is not biology but oppression that produces sexual difference. As the later argues, sexuality is a social construction produced historically and varies cross-culturally. They do not consider sexual behavior as fixed, but fluid and variable. Foucault maintains that sexuality must not be seen as a drive, which is a line and natural, but as an especially dense transfer point for relations of power (Foucault, 1987).

In postmodern debates on sexuality, Foucault's work has been the main impetus that problematizes the "regulatory mechanism which circumscribes the sexualized body" (McNay, 1992). Sexuality is a site that shapes, reproduces, articulates and transforms gender relations. Issue of sexuality is, therefore, integral in the whole spectrum of power relations between women to women and women and men. Sexuality as a concept offers important analytical framework in analyzing the construction of gender regime of power. Foucault argues that sex is a focal point of the exercise of power because it exercises control over the human body (Weeddon, 1987), which he calls "the discursive constitution of the body" (Foucault, 1987). 
Hence, the constructivist conceptualization of sexuality offers a potentially creative and flexible analytical perspective in understanding power relationships between women and men.

Liberal feminists argue that, women have cultivated their beauty or love at the expense of their minds because beauty is the means through which women get power by attracting a husband in household or as a "show piece" and they establish themselves economically. Similarly, women are highly suffered from the men's law. Men's laws have been enacted to destroy her independence, and crush her individuality have violated her essential rights (Dahal, 2008). Society is in equilibrium condition, so, it is necessary to harmonize among men and women so as to exist every culture and society. So, equality between men and women for equal opportunities, roles, responsibilities and for equal rights; further help to create gender balance and gender quality in society. This condition could deliberate comprehensive development approach. Similarly, the involvement and participation of women in the world of labor market is not in smaller in size or volume than men. Women are backward in development in development and specific professionalism are because of the untaken of equal responsibilities for domestic work and family responsibilities by men. If men take equal responsibilities in domestic work and family maintenance, women will develop their professionalism and they can earn and learn like men. Likewise, women must have to struggle for their improvement (ibid).

The differential or unequal rewarding of two sexes and hierarchy among women and of the activities, roles, characteristics and traits associated with them is the subject of this research, the entire process of sex differentiation as a construction of our society and culture is explained with the help of Ratauli songs. In everyday life, however, it is difficult to find social difference without social ranking everywhere. For example channeling graduate girls in the cooking or cosmology classes and boys into trade or shop or auto mechanics, etc. or placing girls in the "soft" science (sociology, anthropology, political science, home science, home economics and management, office secretary etc.) and boys in the "hard" science (physics, chemistry, geology, medical sciences and engineering etc.) means different and unequal occupational opportunities center on. In the real world, gender differentiation and stratification occur together. By this we can conclude that, usually, girls are encouraged to study home sciences because society wants to feel women in love and by love men can be ruled over them. In the name of love and emotion women were, are and will become oppressed, exploited and subordinated (Dahal, 2008).

While studying gender role socialization, male babies get blue blankets, while females get pink ones. Boys are expected to play with trucks, blocks, and toy soldiers; girls are given dolls and kitchen goods. Boys must be masculine- active, aggressive, tough, daring and dominant- whereas girls must be feminine- soft, emotional, sweet, and submissive (Schaefer \& Lamm, 1992). In an illuminating study of differential treatment, a baby was sometimes dressed in pink and called "Adam". Barbara Bovee Polk has summarized the "power analysis' of sex differentiation, which holds that it is in men's interest to maintain power and privilege over women: "Power over women in personal relationships gives men what they want, whether that be sex, smiles, chores, admiration, increased leisure, or control itself. Men 


\section{Macrothink}

occupy and actively exclude women from positions of economic and political power in society. These positions give men a heavily disproportionate share of the rewards of society, especially economic rewards"(Polk,1974 cited in Schaefer \& Lamm, 1992).

\subsection{Relations of Son and Mother;}

Contemporary writers about relationship between mothers and sons from a patriarchal perspective (Lashlie, 2007) demarcate inherent gender differences in parents and campaign for the specific and vital role of the father in making men. Gender difference discourse then becomes the foundation from which the mother is edited out of her son's life as he moves into 'manhood' (O'Reilly, 2008). The feminist mother and son relationship brings together what has, throughout feminist history, been a particularly fraught and contested union (Backes, 2000)

\section{Bhandeu aama chhoro ta mero ho}

Bholi dekhi hereko herai ho

Babu timro ghar banyo bhanye

Brida aaashram jaau aama nabhane

\section{$\underline{\text { Sense in English }}$}

\section{Female;}

Till today (for mother) the son (groom) is your own

From tomorrow your son(groom) will not be your

\section{Mother}

If you make your home

Do not tell me to go old age home (do not get out me)

The above piece of song is expressing the interrelationship between mother and son before and after marriage, before there are comfortable situation of harmonious relationship between mother and son. The relationships changes when the groom brings the bride. After the arrival of bride in groom's home the relationships inside the family undergoes to change. Usually, mother feels the daughter-in -law kidnapped the relationship between the mother and son and daughter-in -law enjoy the power of her husband in behave of his newly married wife and son becomes the distance with the family members. Similarly, there are power tassel in many aspects in between the female powers-mother-in-law, daughter-in-law and sister-in law. There are struggles of power between mother-in-law and daughter-in-law because of patriarchy.

\section{Bhare ta buhari aauche}

Sasu chahi basera tolauche 


\section{Sense in English}

In evening, daughter -in-law comes

Mother-in -law becomes looking by stand is it.

In Hindu society, women are problematic partly because of their association with sexuality and fertility and partly because they are perceived as destructive to agnatic solidarity. But, what gives this ambivalent view of women such power in society is the fact that it is reinforced by reflecting in so many of the conceptual and symbolic structures of Hinduism. According to Bennett, one of the pervasive symbolic structure concerning women is the set of meaning attached to the female body. The body, with its reproductive processes, is a vehicle through which body positive and negative feelings, about women and about sexuality itself are expressed, the ambivalence about one reinforcing the ambivalence about the other. The negative view of sex in ascetic ideology combines with the patriline is mistrust of afford women to produce a deep mistrust of the sexual and seductive aspect of women (Bennett, 1983).

Bennett tries to explain why menstrual blood is a strong source of pollution in Hindu culture (especially in Brahmins and Chhetries), women who are spending or who have been menstruating is in dangerous stage, but if when her menstruation stops, she becomes pure because in Hindu society it is associated with asceticism. Menstrual blood also has some positive connotations through its connections with fertility. In Hindu culture, ascetic ideal provides the high value in the production of offspring and according to village beliefs about the philosophy of conception, menstrual blood is the material out of which-desired children are formed in the wounds. There are four symbolic sin of menstrual blood: one is the connected with the grave sin of Brahman murder, which is polluted and other three are the fire, the river, and the mountain are unaided as purity (Bennett,1983).

According to Bennett, this ambivalence is but another expression of the conflicting Hindu attitude towards sexuality. A woman's menstrual period is when she is most blatantly sexual; and thus strict segregation. For the first three days represents control imposed on the potentially unruly and destructive forces of female sexuality. Through the ritual of bathing, washing their hair and clothes, and the drinking of cow's urine with ritually purifying powers on the fourth day women cleans their sexuality each month and direct it towards its legitimate end, the production of off spring to carry on the lineage. Besides, this monthly purification, there are two other major status in Hindu culture directed at the purification of menstrual pollution and on a deeper level, the channeling of female sexuality. It is clear that, as a consanguine woman (filiafocal kinship), the sister has an absolute purity which even the faithful wife cannot match. It does not matter, how "pure" an affinal woman may be in terms of her own caste pedigree, her virginity at the time of marriage, or her subsequent faithfulness to her husband. She still cannot have the ideal categorical purity is the base of her sacred filiafocal status and of her power to bless her brother with long life (Dahal, 2008).

\subsection{Expression of Sexuality and Vulgarity}

Ratauli songs are dirty and sleazy, it is vulgar and from the looks of it, it is here to stay. 


\section{Macrothink}

Ratauli songs are probably the most popular Nepalese music, from the east to west, and religiously heard by those living abroad. But now a day it is going to change and becoming more vulgar. One of the Ratauli player disguised her and became the male by dress and she mimicry as male. The most of the women satires the mock male mock male and enjoy more, at the moments vulgar expressions were there frequently. Some of the piece of them as;

\section{Mock male}

Balla aayo chhorako paalo

Bhare raati chalauchha bhuichalo

\section{$\underline{\text { Sense in English }}$}

It is the turn of son after long time

There will be like earthquake at the night (expression about sexual intercourse)

Sanu timile bho bhannu baru

Bajho khetle dhanla ta baliyo goru?

\section{$\underline{\text { Sense in English }}$}

Sanu (literally addressed by loving) you will stop to say !stop it is enough

Can virgin vagina meet the strong penis?

\section{Female}

Bajho khet chha aali chha saaro

Jotnu timi le bistarai bistarai

Timi lai nai sumpeyeko chu mero jeu

Herau Kasto charchan unale beu

\section{Sense in English}

Vagina is virgin and labia majora and labia minora are hard or strong

Handle carefully and enter gently to success the break up the virginity

I gave up my body to you

Waiting that how you ejaculate and what type of sperm you spread

Above songs are found the more vulgar directly express the sexual intercourse through the Ratauli songs. One of the participants of the Ratauli said "the Ratauli songs are now completely based on expression of the sexuality especially the sexuality of women while fulfilling the obstinate desires of men and in due process, creating an uncouth image of the whole Nepalese musical field. The whole idea of sexualizing a traditional genre of Nepalese in the name of modernization is infuriating." Another piece of Ratauli sons as; 


\section{Macrothink}

\section{Female}

Dada kaati jaau bhane dhan chaina

Moti ketilai naseko kam chaina

\section{$\underline{\text { Sense in English }}$}

There is no money or property if wanted to go away from home

I am fat women and you are useless because you are thin one

\section{Mock male}

Yo motiko bishwas nai lagdaina

Moti thakchha nase ta thakdaina

Jorpatima garyethiyeu helaa

Aaiya niya garaula tyo bela

\section{$\underline{\text { Sense in English }}$}

I do not have (never) trust on this fat woman

Usually, fat women tired but thin male never tired

(in the course of sexual intercourse)

\section{Female}

Deusai timile dekhya chau sapani

Baukai chhori kam chaina ma pani

Malai bhare bho bhanni paryeu bahne

Bau kai chhora bhanaula ma pani

\section{$\underline{\text { Sense in English }}$}

You see the dream in day time

I am not that weak person; I am also the daughter of my brave father

If you will make me enough, and satisfied

Then, I will accept you are also the son of brave father

\section{Mock male}

Yeta hera manche chahi chito chu

Pir nagara boka jhai chito chu

\section{$\underline{\text { Sense in English }}$}


Look at me, I am faster

Do not worry; I am like faster as 'male-goat'

\section{Female}

\section{Timile sekhi gardai chau aruko}

Bhare herchu boka ho ki goru ho

\section{$\underline{\text { In English }}$}

You are jealous with others

I will see you as like male goal or like bullock

All from these pieces of songs, we can conclude that, Ratauli songs express the sexist signs, symbols, message, verbal, and so on because of patriarchy and male control over the mobility and sexuality of women. Male usually perceive female as the objects of sexual entertainment and means of sexual pleasure. That's' why mostly Hindu women in Ratauli express their opinions arguments against the patriarchy and male dominance on female mostly sexuality through the satires and verbal and non verbal symbols using the character of mock male through mimicry. Because of male ideology of bravery and sexism are the reward of male in Hindu orthodox society and women are the means of sexual pleasure of male, women's commentary on male control over female through the mimicry and satires usually sexual in expression.

One of the participants shared her view as "there is a thin line between "glamour and obscenity ", but in case of Ratauli there is more obscenity than glamour and women enjoyed more in such songs rather than other ordinary songs". It is found from the study of Ratauli songs which were listen during the field work, that the recurrence of sexism and misogyny in Ratauli songs might render the issues of gender, sexuality and cases of abuse as insignificant. Its repetition can make people accept the views of the songs. "If these kinds of entertainment songs are to continue, there should be some kind of information provided to singers and listeners to tell them that what they are singing and listening too is adult content or needs social and cultural enforcement for guidance.

\subsection{Anthropological Perspective on Ratauli Songs}

The laughing, singing, and dancing in Hindu orthodox society then, represents a complete reversal of the Hindu ideal of womanly behavior. To say that a girl is shy, embarrassed is to praise her highly. In Ratauli, the high spirits, the flirtatiousness, the sexuality which women must ordinarily suppress are expressed through the songs in that event. The dangers of female sexuality are thus firmly bracketed by the mutually reinforcing ascetic and patrilineal ideals (Bennett, 1983). Usually, in Ratauli festival women sing songs of beauty, cosmetics, sexy and many more which basically express their pretty, sex as biological need, wearing ornaments and performance on their gatherings. 'How to be pretty' and 'how to concentrate others' attention' are main concern of women during this festival, because sex is reward for every male and beauty is the gift for female. To show-up and be brave males are ready to do 
everything and to be pretty females are ready to do everything. Furthermore details will be described as following Ratauli songs

Women are sacred in filiafocal system, they are pure when they are unmarried and at that time females also rank over males. But, when women get married and involved in procreation of children, then she becomes polluting. And later when menstruation stops and they are incapable for reproduction of child or celibacy they again become pure. That's why fertility determines status of women, when women are beyond the fertile stage or before their marriage; her status is assumed as sacred. When women enters married life, i.e. from filiafocal to pontifical, women becomes "polluted" because of "fertility" and she will be "danger" because she may break family, fragment land and capture the son of "mother-in-law". So, clash between mother-in-law and daughter-in-law emerges and it is the condition of inter gender symbolic conflict. But, there is also existence of inter-gender symbolic conflicts between male and female or husband -wife (Dahal, 2008).

The social power relation between the men and women are made very blatant. How the women concentrate on making themselves beautiful either for men's benefit or to succeed in the 'marriage trade', can be seen. Either it is the women's beauty (clear, fresh, white skin or lovely complexion), which is her saleable aspect and 'being beautiful' therefore becomes the women's trade. But the men are never referred to as beautiful. They are distinctly dressed or are presented as 'millionaires.' It is good clothing rather than beautiful skin, which are essential to the men's getup or attire. The men are therefore clearly linked to the world of business or trade implying a 'provider' role while the focus for woman is on her being a woman that does not 'make mistakes' and is perfect for the man. The sexual romance a part as opposed to the functional part of the relationship between women and men therefore begins to gain greater prominence in the ideological representations.

The woman or wife is in all senses living for the man, not for her. She looks beautiful for him, makes him smile and in fact her 'labor' is even described as a tough job, which is valuable because it's worth at present. She works for love while he works for economic benefits. With the changed commodity markets today, women have been defined as consumers have sex objects and are related to as commodities. In advertisements for instance, we can see the assumed (hetero) sexual romantic connection between the women and the men. It is the men's power and control, which is emphasized in this relationship. Everywhere man is the special guest. In social gatherings, he stands still and others circulate. The poise of woman subtly implies that it is not only the waiters who wait on the man whose look prompt service; it is the woman who is romantic or sexual sense waits on him as well. Man is thought to be a leader and a 'magnet' among women. Again the poise of woman suggests that she exists to be drawn towards the 'magnet' (i.e. the man) in order to support and serve him. The man's smart look and expensive dresses also imply that he has economic power.

What type of Ratauli songs are formed in specific time and context was tried to visualize clearly. Various researches, empirical data, theoretical proponents and relevant model along with references helped to crystallize thematic issue i.e. "women through Ratauli songs" was conceptualized and contextualized in Nepalese culture and society by analyzing Ratauli songs. 
The main objective of thematic review was to study and explain the subject matter based on the society and culture, structure of lyrics depends on socio-cultural construction and it depends highly on context of that socio-cultural setting.

The questions of 'Ratauli: ritual or recreation' was tried to analyze here, where mythical, recreational dimensions were described. Most of the social and cultural values were focused on sexuality and beauty of women as reward in every society and culture, whereas male showed the sexism and bravery as reward for them. Social and cultural constructions were also not away from the analysis, because they were also expressed in Ratauli songs very tactfully, and with full of weaving through facts and figure. Songs in control on mobility and sexuality, domination of male over public and private spheres, that were the result of sociocultural matrix also the outcome of patriarchal socio-cultural products. Gender relations-intra and inter- gender relations got prime value in lyrical analysis of Ratauli songs, where relations between men and women and women-women was in central of analysis.

The focus of the Ratauli song sung by women about how they miss their husbands gone in search of work, the socially oppressed expressing their woes through their sons and daughters-in-law lamenting about the hardships at their husbands' were woven into stories which formed the base of the current situation of migration along with other social problems of Nepalese Ratauli genre. Due to various reasons; economic, migrations, unstable government along with various problems, It was basically our version of 'the blues'. In a country with deep-rooted cultural biasness and basically indoctrinated by religious mistranslations, 'Ratauli ' for our previous generations was also a medium of entertainment and courtship as mild flirtations and teasing from both gender was considered normal, but in case of this generation it is new and to socialize all these things to sustain the cultural features. Society and cultures are dynamic so, things change, always, and they have changed drastically for the Ratauli genera.

Ratauli singer, dancer or participants of Ratauli, all are wearing gaudy and skimpy clothes, and keener on exposing their body parts. From orthodox Hindu ideology it is said that the paradigm has shifted to Ratauli songs becoming a ubiquitous display of vulgarism and social perversions. The meaningful and elegantly poetic compositions classical Ratauli singer's voices on Ratauli era have been replaced by cheap, commercial excuses for songs that basically circle around lust, sex, physical attraction and the many perversions of the 'modern' Nepalese society.

Various socio-political changes, economic changes motivate to change in value system, life pattern, status and position of women have been changing day by day and male representations of female sexuality provide patterns that fit into the accepted structure of behavior, beliefs that provide a source of permissible metaphors through which people think about themselves, standards for behavior, and exemplars learned from the anonymous pressure of ascribe social mythology.

\section{Conclusion}

It is also found that the contents (lyrics, messages) of the Ratauli songs to the people of the 


\section{Macrothink}

Journal of Asian Development

ISSN 2377-9594

2021, Vol. 7, No. 1

Hindu society have been expressed in this article, were the byproducts of socio-cultural context our society and culture and life experiences of women. Love, harmony, conflicts, associations, relations, role responsibilities etc. of women-men and women were analyzed through the Ratauli songs. So, the study of Ratauli songs efficiently provide the clear cut understanding about Hindu society, culture, gender relation, power structure, role and responsibilities and intra and inter women relationships were also studied through the Ratauli songs.

The study found that Ratauli songs were actually more focus on the women's world. It generally comprises structure and construction of Nepalese society; especially women's sexuality in Hindu society and it importantly covers the recreations, satires, singing, dancing, mimicry and so on to create the joyful and entertainment environment in Ratauli. Ratauli songs thus provides a means for environment to interact completely and perfectly, it helps to develop the social solidarity, harmony among women in Hindu society in a way and in another way it comments, satires the male and patriarchy to hinder the development of women because of orthodox attitudes and value system regarding the women's right, duty, mobility and sexuality which is controlled by men, patriarchy and women as agent of men and patriarchy.

\section{References}

Backes, N. (2000). Beyond the World of Guilt and Sorrow. Separation, Attachment and Creativity in Literary Mothers and Sons. Journal of the Association for Research on Mothering, 2(1), 28-45

Bakhtin, M. M. (1986). Speech Genres and Other Late Essays, Trans. Vern W. McGee, Austin, Tx: University of Texas Press

Bateson, G. (1979) Mind and Nature; A Necessary Unity. New York: Bantam

Bennett, L. (1983). Dangerous Wives and Sacred Sisters: social and symbolic roles of High Caste women in Nepal. New York; Columbia University press.

Cuff, E. C., Sharrock, W. W., \& Francis, D.W. (1990). Perspectives in Sociology (3rd Ed.). Unwin Hyman Ltd. London.

Dahal, B. P. (2008). An Analysis of Nepali Culture and Society. Kathmandu: Benchmark Education Support Pvt. Ltd.

Feld, S. (1982). Cf.; 1990/1982 Sound and Sentiment: Birds Weeping, Poetics and Song in Kaluli Expression. Philadelphia: University of Pennsylvania Press.

Feld, S. (1984a). Communication, Music and Speech about Music. Yearbook for Traditional Music, 16. https://doi.org/10.2307/768199

Foucault, M. (1987). The History of Sexuality, trans. Robert Hurley (Vol. 2). Harmondsworth: Penguin.

Geertz, C. (1973). The interpretation of Cultures. New York: Harper Collins Publishers 


\section{Macrothink}

Journal of Asian Development

ISSN 2377-9594 2021, Vol. 7, No. 1

Kondos, V. (2004). On the Ethos of Hindu Women; Issues, Taboo and Forms of Expression. Mandala Publication, Kathmandu Nepal.

Lashlie, C. (2007). He'll Be Ok: Growing Gorgeous Boys into Men. Auckland: Harper Collins

Levi-Strauss, C. (1969). The Elementary Structures of Kinship, translated by J. H. Bell, J. R. Von Sturmer and Rodney Ne dham,(ed). Boston: Beacon Press.

McNay, L. (1992). Foucault and Feminism. Cambridge; Polity Press.

O’Reilly, A. (2008). Feminist Mothering. New York: SUNY Press.

Schaefer, R. T., \& Lamm, R. P. (1992). Sociology (4th ed.). McGraw- Hill: Inc.

Seeger, A. (1987). Why Suya Sing: A Musical Anthropology of an Amazonian People.

Stokes, M. (1994) (ed.) Ethnicity, Identity and Music; The Musical Construction of Place. Oxford: Berg Publishers.

Weedon, C. (1987). Feminist Practice and Post-Structuralist Theory. Oxford: Basil Blackwell.

Weisethaunet, H. (1998). The Performance of Everyday Life; The Gäine of Nepal. Oslo: Scandinavian University Press.

\section{Copyright Disclaimer}

Copyright for this article is retained by the author(s), with first publication rights granted to the journal.

This is an open-access article distributed under the terms and conditions of the Creative Commons Attribution license (http://creativecommons.org/licenses/by/4.0/). 